\title{
A Massacre Foretold: National Excommunication and Al-Gama'a
}

\author{
WALTER ARMBRUST \\ St Antony's College, Oxford University
}

\begin{abstract}
Al-Gama'a [The Society], a 28-part television biopic of Muslim Brotherhood founder Hasan al-Banna, was broadcast in the fall of 2010, just before the January 25, 2011 Revolution. The writer of the series, Wahid Hamid, was an important screenwriter for both television and the cinema and a figure known for his affinity with the state's security apparatus. Al-Gama'a functioned as a rhetorical capstone for decades of anti-Brotherhood state discourse. It also powerfully anticipated the anti-Brotherhood apologetics used to rationalize the Rab'a Massacre of 2013, which effectively ended the revolution and cemented the coup by 'Abd al-Fattah al-Sisi against Muhammad Morsy. The series enacted a historical narrative that was almost completely absent from Egypt's formal educational curriculum, thereby furthering a political agenda of dehumanizing Islamists and effectively excommunicating them from the national community. Hence in 2013, a thousand Egyptians were slaughtered in a day, and yet many of their fellow citizens saw the event as destiny rather than as a crime against humanity.
\end{abstract}

Keywords: Hasan al-Banna; Muslim Brotherhood; Egypt; Wahid Hamid; January $25^{\text {th }}$ Revolution; television series

When the Rab'a Massacre occurred on August 14, 2013, it seemed shockingly at odds with the recent succession of elections in which the Muslim Brotherhood had won every time. How could the public turn on the Brotherhood so swiftly and decisively? Many observers tended to explain the collapse of support for the Brotherhood as a consequence of the revolutionary politics that had unfolded since the beginning of 2011, when the regime of Hosni Mubarak had collapsed suddenly and unexpectedly. In this article, I argue that support for the Muslim Brotherhood by non-Islamists had been conditional on the Brotherhood's capacity to disprove a dehumanization that had been instilled in the public for a long time, and that all the arguments used to justify the massacre in 2013 were already in play in the public sphere before the Revolution began. The Revolutionary events of 2011 were at best a trigger for certain publics already opposed to the Brotherhood, in effect, to pull off the discursive shelf well-rehearsed arguments about the Brotherhood's essentially alien status within Egyptian society.. My vehicle for instantiating this argument is a musalsal — a television serial— titled Al-Gama ' $a$ [The Society]. 
Al-Gama ' $a$ was a 28-part narrative broadcast in Ramadan of 2010 (from August 10 to September 9). ${ }^{1}$ The series depicted the life of Hasan al-Banna, the founder of the Muslim Brotherhood, from his childhood in the Delta town of Mahmudiyya, beginning during the First World War when al-Banna was about 10 years old, until just before his assassination in 1949 . Of course, the story of al-Banna's life was also the story of the Muslim Brotherhood.

Al-Gama' $a$ was temporally complex, unfolding through a juxtaposition of contemporary time and the time of Hasan al-Banna. The contemporary story begins with the character of Ashraf, a wakil al-niyaba - a public prosecutor responsible for investigating criminal cases on behalf of the state. Ashraf is asked to investigate a case involving a demonstration by Muslim Brotherhood students who had been expelled from al-Azhar University due to their political activities. Some of the students in the demonstration wore black balaclavas and performed martial arts routines. The authorities interpreted this behavior as militia activity, essentially a menacing flexing of muscles by the Brotherhood. The event depicted in the serial was based on a real incident from 2006. The circumstances were contentious. ${ }^{2}$ The Brotherhood claimed that their Kungfu and karate routines, as they were called in the press, were merely an athletic display, and that the ruling party was using it as a pretext to crack down on the leadership. The state and the National Democratic Party insisted that the display was essentially military, and that it was hugely alarming.

When Ashraf begins his investigation, he is shocked to discover that he knows one of the students being investigated. The young man is from a family linked to Ashraf's own family. Astonishingly, none of the boy's relatives had any idea that he was a Muslim Brotherhood

Correspondence address: Walter Armbrust, St Antony's College, Oxford University, Oxford OX2 6JF, UK; Email: walter.armbrust@sant.ox.ac.uk

${ }^{1}$ Muhammad Yasin (2010) Al-Gama 'a (The Society) (Cairo: Sharikat al-Batrus lil-Intag al-Fanni wa al-Tauzi').

${ }^{2}$ Ahmad al-Buhairi (2006) Milishiyat 'Ikhwaniyya' Tasta'rad Maharat Qitaliyya Dakhil Jami'at al-Azhar [Brotherhood Militias Show Off Their Fighting Skills Inside Al-Azhar University], In Al-Masry al-Yaum (Nov. 12), available at: http://today.almasryalyoum.com/article2.aspx?ArticleID=40525, accessed on 24 July, 2018; Milishiyat al-Ikhwan fi alAzhar [The Brotherhood Militias in al-Azhar] (2012 [from 2006]); available on Youtube at:

https://www.youtube.com/watch?v=VMPpGR-Pc3k, accessed on 24 July, 2018; and Haqiqat Milishiyat al-Ikhwan fi alAzhar [The Truth about the Brotherhood Militias in al-Azhar] (2006), available as Youtube video at: https://www.youtube.com/watch?v=B 2sFWzj4E, accessed on 24 July, 2018. 
member. Suddenly confronted with the unexpected complexity of the case, Ashraf realizes that although the Muslim Brotherhood has been a semi-public presence in society throughout his life, he knows next to nothing about the organization. Ashraf tries to recuse himself from the investigation on grounds of his personal connection to one of the suspects and his ignorance of the organization to which he belongs. However, Ashraf's superior refuses his request for recusal. So Ashraf embarks on a quest for knowledge, his own personal mission to understand what the Muslim Brotherhood really is and where it came from. The quest leads to his finacée, Shirin, a well-off young woman who works as a frustrated employee of a mobile phone company, but who in the course of the narrative quits her job and starts working as a journalist. The crucial narrative role played by Shirin is to connect Ashraf with her grandfather 'Abdallah. He is a gruff old retired judge. His career in the same field in which Ashraf works helps to bind them together. More importantly for the narrative, 'Abdallah happens to have been a member of the Muslim Brotherhood in his youth, and he knows their history thoroughly. It is through 'Abdallah that the serial develops its historical track, which gradually crowds out the contemporary track over the course of the 28 episodes, as his narration of Hasan al-Banna's story in the present segues into a re-enactment of al-Banna's life in the past. ${ }^{3}$

The contemporary track in Al-Gama 'a was heavily nostalgic, as was the historical strand. A scene from the contemporary story provides a crystal-clear articulation of nostalgia. It is also a rather chilling scene for reasons that will become apparent. It comes in episode 10, by which time relations between Ashraf's and Shirin's families are warming up, as the couple become more serious about their marriage plans. The historical track depicting Hasan alBanna's life, as related through the retired judge 'Abdallah, Shirin's grandfather, is also heating

\footnotetext{
${ }^{3}$ This begins in episode 4. Everything before that is set entirely in the present. Between episode 4 and episode 20 , the story alternates between the modern and historical tracks. Just after the first few minutes of episode 20, the modern track disappears entirely. Episodes 21 through 28 simply tell the story of Hasan al-Banna and the Muslim Brotherhood until just before al-Banna's assassination. A second season of the serial was planned, to cover up to the execution of Sayyid Qutb in 1966. Part 2 was delayed by the Revolution, but was eventually broadcast in 2017, to much less fanfare than the first season. Part 2 completely dropped the contemporary strand of the narrative in favor of a straightforward enactment of historical events.
} 
up. In the historical track of the serial we reach the late 1920s - the moment that Hasan alBanna's followers in the fledgling Muslim Brotherhood decide that they have to devise a name for their leader. In that scene Al-Banna and his followers are sitting cross-legged on the floor of a village mosque in the Suez Canal town of Isma'iliyya, where al-Banna is employed as a school teacher. One of his followers suggests ' $r a$ 'is' as the title_-'president,' but also just “chief' of something. But al-Banna won't have it. He won't go for "shaykh" either. "The head of the Muslim Brotherhood must have a newly invented name for which there is no equivalent. $A l$ Murshid ('The Guide'), and thus Fadilat al-Murshid, 'His Excellency the Guide' becomes his title. It is a relatively light-hearted scene in a production that takes itself very seriously, but still functions to convey al-Banna's sense of self-importance and boundless ambition. A few minutes later al-Banna articulates his vision of the Muslim Brotherhood expanding to cover not merely all of Egypt, but the entire Muslim world.

The scene that so clearly articulates nostalgia in the contemporary strand of the serial is a negative echo of al-Banna's ambition as expressed in the historical track. It comes just before the 'murshid not ra' $i s$ ' scene described above. The cast of characters includes Ashraf, the young Wakil al-Niyaba investigating the history of the Muslim Brotherhood, and Ashraf's mother Sua'd, an elegant middle-aged woman. The third person in the scene is Shirin, Ashraf's fiancée. And finally, the scene features 'Abdallah, Shirin's grandfather, a slightly crusty personality, and as previously mentioned, a former member of the Muslim Brotherhood.

Up to this point in the series 'Abdallah has been telling Ashraf the story of the Brotherhood Shahrazad-style, in an endlessly unwinding narrative that provides pretexts for the television serial to go back in time. At this point they're in the countryside, at 'Abdallah's 'izba - a family farm. It's somewhere in the Delta, probably not far from the events of Hasan alBanna's youth, a location that the historical track of the program has been enacting since episode 4. In the contemporary scene they have just finished dinner. Ashraf and Shirin get up to

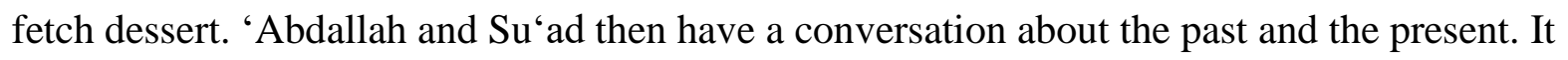


appears that there is a bit of romance developing between the two old folks, maybe spurred on by the impending marriage between the younger couple. Ashraf and Shirin have not completely withdrawn — they stand in the doorway listening.

'Abdallah (to Su'd): Can I ask you a question?

Su'ad: Of course. At your service 'Abdallah Bey.

'Abdallah: I wonder if our time was better than it is for these kids now?

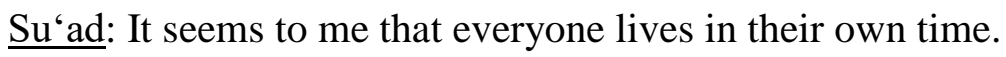

'Abdallah: But our times were better. Remember when peoples' faces were smiling and laughing?

Su'ad: Remember when we were light-hearted?

'Abdallah: Remember when people used to love each other?

Su'ad: Remember when women could walk in the streets unafraid and self-assured, out walking their kids with their baby carriages in front of them?

'Abdallah: Remember when men and women could sit together at a football match?

Su'ad: Remember how people used to look at an Umm Kulthum concert?

$\underline{\text { Shirin }}$ [watching and listening with Ashraf from the doorway]: Why are they making us hate our own times?

$\underline{\text { Su'ad: }}$ Young lady, this is how it is supposed to be for all times.

'Abdallah: If I knew who ruined our lives and stole the joy from our hearts and minds, and if I were still serving as a judge, I would sentence him to death!

There is no clear indication that 'Abdallah's last line in the scene — the one in which he says he would sentence the man who 'stole our joy' to death-was intended to be taken as rhetorical. It is true that he was talking about a man who was long dead, so perhaps we are not meant to take it literally. For many real people, however, 'Abdallah's wish came true almost exactly three years later, when the Egyptian security forces broke up a six-week-long sit-in by supporters of deposed President (and member of the Muslim Brotherhood) Muhammad Morsy 
at the Raba' al-'Adawiyya Mosque in Madinat Nasr, killing at least 800 of them. ${ }^{4}$ Not everyone acknowledges the Raba' massacre as an atrocity. Even today some claim that the event was staged, or that the massacre was a legitimate response to Brotherhood provocations.

In keeping with the notion that the Brotherhood's tragedy was brought on by their own actions during the Revolution, the ground was prepared to deny responsibility for the impending loss of life in the weeks leading up to the clearing of the sit-in. The press and the television media were full of lurid tales about a buildup of 'heavy weapons' in the area, which the Brotherhood would use to inflict massive casualties on the security forces. ${ }^{5}$ In the weeks between the coup on July 32013 , and the massacre during the clearing of the Rab'a sit-in, the media - all of it non-Islamist once the pro-Muslim Brotherhood television channels and newspapers had been closed down - hammered away at the Muslim Brotherhood. The weapons narrative was among the most prominent strands of the campaign. One of the most sensational reports on 'heavy weapons' was presented on a television talk show two weeks before the massacre. The television presenter, Ahmad Musa, is known for his high-pitched emotional outbursts and for being slavishly devoted to the al-Sisi regime. The video report showed six bearded men carrying a long object wrapped in an Egyptian flag through crowds in Rab'a. According to his own report, Musa could not quite identify the object, but that did not stop him from declaring it a 'heavy weapon':

\footnotetext{
${ }^{4}$ Human Rights Watch (2014) All According to Plan: The Rab 'a Massacre and Mass Killings of Protestors in Egypt (New York: Human Rights Watch). The occupation of the Rab'a and Nahda squares had begun soon after the coup that removed Morsy from power on July 3. The proximate reason for the delay was that it was Ramadan from July 8 to August $7^{\mathrm{t}}$. However, 'Abd al-Fattah al-Sisi also needed to consolidate his grip on power with respect to both domestic politics and to international relations. With regard to the former-domestic politics - many of the protestors who marched in protests against Morsy wanted to remove him in favor of new elections rather than to install the military. A political process was necessary to quell the objections of this segment of the public. With regard to international relations the new regime needed to demonstrate the popularity of its seizure of power, which it did on July 24 by calling for a massive demonstration designed to grant a popular tafwid [mandate] to the army to 'fight terrorism.'

${ }^{5}$ Al-Mukhabarat al-Amrikiyya Tarsud Asliha wa Qanabil bi-Dakhil I'tisam Rab'a [American Intelligence Monitors Weapons and Bombs Inside the Rab'a Occupation] (2013) Waqa' $i$ ' al-Hadath, 29 July: http://www.elhadasnews.com/28279.html; accessed on 24 July, 2018; Darin Farghali (2013) Al-Liwa' Faruq alMaqrahi: Fadd I'tsamay Rab‘a wa Nahda Yakun 'ala 3 Marahil [General Faruq al-Maqrahi: The Dispersal of the Ra'a and Nahda Occupations in Three Stages] al-Watan (archived in Masress), 3 August:

https://www.masress.com/elwatan/237512 accessed on 24 July, 2018; Asliha Thaqila fi Rab'a [Heavy Weapons in Rab'a] (2013) Youtube video from a report in the newspaper al-Yaum al-Sabi', 29 July:

https://www.youtube.com/watch?v=cfA9qWK8eS8; accessed on 24 July, 2018.
} 
... clearly the thing has some sort of muzzle, of a cannon or something. The main thing is that it's weapons. Go a bit further in the video [said to the camera man off screen running the video for him $]$... a little further ... yes ... do you see? That's the complete picture, and they're not carrying a body; it's an act. They're laughing, you can see how they're smiling, those killers who are carrying weapons. Do you see the smiles? And it's wrapped in the Egyptian flag. The Egyptian flag! Which is innocent of this bloodiness, innocent of these killers. And the criminals carrying it-it's a type of ... I don't really understand military stuff, that takes a weapons expert. But clearly it's maybe a kind of mortar, maybe a portable cannon or something like that. Fast forward a bit Hisham, I want to see it from the rear ... yes ... if someone ... see ... yes, stop here. It's the part that's sticking out on the top. It's some sort of tube, I don't know, it needs some special assembly, but you can be sure that there are weapons in this area. ${ }^{6}$

When the security forces finally cleared Rab'a on August 14' the notion that supporters of Muhammad Morsy in Rab'a were defending themselves with "heavy weapons" as the media often put it — cannons, machine guns, mortars, or at the very least military assault rifles — was revealed to be utterly without credibility. ${ }^{7}$

With respect to the subject at hand, it is important to observe that in the summer of 2013 , large segments of the non-Islamist public in Egypt seemed remarkably receptive to the sort of transparently false propaganda that Ahmad Musa was peddling. The details of what really was happening in Rab'a and a sister occupation in Nahda Square in Giza were of little concern to the loudest voices in the media. If the "heavy weapons" story didn't pan out, then plenty of other

\footnotetext{
${ }^{6}$ Asliha Thaqila fi Raba' video.

${ }^{7}$ The Egyptian Ministry of Health claimed that 43 of the approximately 800 dead were members of the security forces. The independent (and more reliable) Wikithaura group put the number of security forces casualties at 8; see Taqrir Shamil: Hasr Dahaya Fadd I'tsam Rab'aa Tafsiliyan [The Complete Report: The Tally of Victims of the Dispersal of Rab‘a in Detail] (2013) Wikithaura, available at: http://wikithawra.wordpress.com/2013/09/03/rabiadisperal14aug/; accessed 24 July 2018.
} 
rumors were circulating on television talk shows and in the press, and they served equally well to dehumanize the Muslim Brotherhood. For example, one often heard that the Muslim Brotherhood was paying poor people from the countryside to stay at the Rab'a sit-in, knowing that they eventually would be slaughtered and thus essentially using them as pawns or human shields; ${ }^{8}$ or that the Brotherhood was capturing innocent non-Islamist civilians and torturing them in rooms hidden beneath the bleachers that had been set up for speeches $;^{9}$ or that the Brotherhood tried to coerce women into 'jihad marriages' [jihad al-nikah], essentially to serve as sex slaves. ${ }^{10}$ While such stories were as dubious as Musa's cannon monolgue, they served to reinforce negative views of the Brotherhood.

Evidence was of little consequence because the court of non-Islamist public opinion already had reached its verdict by the time the massacre occurred: guilty. But guilty of what exactly? When the Rab'a massacre happened, many observers were surprised at the lack of concern and even callousness displayed by non-Islamists. I do not want to suggest that this was a uniform attitude. Among people I knew, reactions to Rab'a varied from grotesque brutality"I'm in favor of eradicating the Muslim Brotherhood," as one of my acquaintances put it - to sincere horror that neighbors and even friends were at risk of being slaughtered. But if there was diversity of opinion in private, very little of that diversity was revealed in public statements about what happened. I remember a colleague at Oxford being absolutely baffled by Rab`a. "Where did that cruelty come from," he wondered. "For two years the Muslim Brotherhood wins every election. Then a thousand of them get murdered in one day and the whole country just collectively shrugs its shoulders. I just don't get it.”

\footnotetext{
${ }^{8}$ The majority of people killed in Rab'a were from Cairo and fit a basically middle-class profile. See Neil Ketchley \& Michael Biggs (2015) "Who Actually Died in Egypt's Rabaa Masacre?” in Washington Post, August 14; available at: http://www.washingtonpost.com/blogs/monkey-cage/wp/2015/08/14/counting-the-dead-of-egypts-tiananmen/; accessed 24 July 2018.

${ }^{9}$ I'tisam Rab'a al-'Adawiyya: al-Ta'dhib bi-Ism al-Shar'iyya [The Rab'a al-'Adawiyya Occupation: Torture in the Name of Legitimacy] (2013) al-Masry al-Yaum July 22; available at: http://www.almasryalyoum.com/news/details/239210; accessed 25 July 2018.

${ }^{10}$ Fadiha min al-'Ayar al-Thaqil Shuf Jihad al-Nikah fi Rab'a al-'Adawiyya [A Scandal of the Greatest Magnitude: See the Jihad of Marriage in REab'a al-'Adawiyya] (2013) Youtube video: https://www.youtube.com/watch?v=PvzwkyVSDxA, accessed on 5 December, 2018.
} 
Of course, on one level the collective shrug was only what the media was allowed to reveal. The evens at Rab'a horrified or outraged a large proportion of the country. . The core membership of the Muslim Brotherhood numbered at least in the hundreds of thousands, and millions of others were sympathetic to it. They protested vigorously, before and after Rab'a. But their protests increasingly were confined to back streets and ignored by the media. Nonetheless, my colleague still had a point about the callous reaction to Rab'a. It took the non-Islamist part of the country two and one-half years to move from a moment of communitas in Tahrir Square, when everyone seemed to love everyone else, to a moment of substantial indifference at the spectacle of a thousand of their countrymen being killed by a military regime that most of the non-Islamist revolutionary forces had also opposed. Certainly, there was a feeling of betrayal from the apparent deals the Muslim Brotherhood had made behind the backs of the non-Islamist revolutionaries. And yes, there was tremendous resentment at the political opportunism of the Muslim Brotherhood. It was by no means unreasonable to protest Muslim Brotherhood rule. But is this really enough to explain indifference to mass murder?

We might think of the Muslim Brotherhood as having been subjected to a kind of national excommunication, a banishing from the social and political body, and therefore deemed unworthy of mourning. As Judith Butler put it in her book Frames of War, 'The differential distribution of grievability across populations has implications for why and when we feel politically consequential affective dispositions such as horror, guilt, righteous sadism, loss, and indifference.' ${ }^{12}$ One can find sophisticated explanations for the ungrievability of the Muslim Brotherhood, ${ }^{13}$ and in my experience it often emerged in conversations with non-Islamist interlocutors, both Egyptian and non-Egyptian. The rhetoric took various forms: the Muslim Brotherhood were 'more a cult than a social or political movement'; 'they were opportunists, beholden to foreign agendas and were not really Egyptians'; they were 'sheep-like followers enslaved by cynical leaders'; they were 'a state within a state, with their own economy and their

\footnotetext{
12 Judith Butler (2009) Frames of War: When is a Life Grievable? (London: Verso), p. 24.

${ }^{13}$ See Hazem Kandil (2014) Inside the Brotherhood (Cambridge, UK: Polity Press), pp. 1-2.
} 
own military capability'; they were 'opposed to culture in principle, devoid of any artistic or humanistic impulse.' The Brotherhood was, in summary, defined as alien to the nation, and moreover as an alien presence that had achieved the status of political rulers. In the eyes of many, this made their removal from power by any means necessary not just tolerable, but imperative, and certainly not cause for an apology.

My purpose is not to try to evaluate such arguments in detail, nor will I try to defend the Muslim Brotherhood. The most effective stereotypes are always built around grains of truth, but selectivity, oversimplification and lack of context turns them into falsehoods. What I would like to suggest is that many of the arguments for national excommunication of the Muslim Brotherhood already were well delineated and thoroughly rehearsed before the Revolution began in 2011. The effect of these arguments was to make evidence secondary to belief. Popular culture played a significant role as did the formal teaching of history, or more precisely a lack thereof. This, at any rate, is the premise of the modern track of Al-Gama' $a$ - that the young public prosecutor Ashraf feels he knows so little about the Brotherhood that he tries to recuse himself from an investigation involving them. ${ }^{14}$ His request for recusal might be a slightly idealistic twist in the plot of Al-Gama' $a$, as it is implausible that he would not have formed prejudgements about the organization. But his lack of formal historical knowledge about the Brotherhood is realistic, even if his urge to impartiality is utopian.

\section{New sub-head here}

Al-Gama ' $a$ broadcast just a few months before the January 25 Revolution, and was certainly the most elaborate narration of popular Ikhwan-ology to which the public had been exposed. In the remainder of this essay I will unpack the historical track of Al-Gama ' $a$ a bit more, focusing on certain scenes that illustrate some of the arguments for excommunication.

\footnotetext{
${ }^{14}$ How modern Egyptian history is actually taught in public schools and universities is beyond the scope of this essay. Anecdotally one often hears that modern history is scarcely offered in Egyptian public education at the secondary level, and to the extent that it is offered, history curricula are highly politicized.
} 
Al-Gama ' $a$ was the most expensive television drama ever made in Egypt up to the year 2010, with a budget of roughly 50 million Egyptian pounds, which then was around $\$ 8$ million.${ }^{15}$ At that time in the Egyptian television industry, such finance could pay for essentially film-like productions. The director of the film, Muhammad Yasin, was a fairly undistinguished young director, although he clearly was able to assemble a quite lush looking historical tableau with such a budget. Wahid Hamid, who wrote the script for Al-Gama ' $a$ is far more important. Over a career spanning five decades, he has written for every medium - theatre, ratio, television, and cinema--as well as short stories and political articles. ${ }^{16}$ Through his film screenplays in particular, Hamid is known as a strongly pro-Mubarak regime intellectual, though it would be an oversimplification to say that he simply writes propaganda. Indeed, one of his writing credits is for the film Al-Bari' [The Innocent] in 1986, which is one of the boldest political films ever made in Egypt. ${ }^{17}$ It depicts the brutality of the military prison system both toward political prisoners incarcerated by the state, and toward the poor conscripts who are compelled to serve the state's vast security apparatus. In the early 1990s, a few years after Al-Bari', Hamid teamed up with actor 'Adil Imam for a number of films that steadily shifted his political horizons toward the regime, though his work is still often tinged with a degree of social criticism that gives his narratives greater public legitimacy than he would have if he were merely an obedient producer of propaganda. ${ }^{18}$

\footnotetext{
${ }^{15}$ Nelly Yusuf (2010) Jadal Haula Musalsal 'al-Jama'a' al-Misri [Arguments about the Egyptian Series al-Jama‘a], in Qantara, 7 (September, available at: http://ar.qantara.de/content/jdl-hwl-mslsl-ljm-lmsry-mslsl-ljm-hrb-lmy-m-drm-fny; accessed 25 July, 2018.

${ }^{16}$ Wahid Hamid (2018) Elcinema, available at: http://www.elcinema.com/person/1087034/, accessed 25 July 2018 ; and Yaqut al-Dib (2012) Wahid Hamid: Ga'izat al-nil Takhtar Man Yahmiluha [Wahid Hamid: the Nile Prize Selects One Who Merits It] in al-Qahira, archived in Masress, available at: https://www.masress.com/alkahera/4227; accessed 25 July 2018.

17 'Atif al-Tayyib (1986) Al-Bari' [The Innocent] (Cairo: Samira Ahmad and Safwat Ghattas).

${ }^{18}$ The turn toward more state-friendly narratives started with Sharif 'Arafa's film (1991) al-Lu 'b ma' al-Kubar [Playing with the Grownups] (Cairo: 'Isam Imam), and then crystallized with (1992) al-Irhab wal-Kabab [Terrorism and Kebab] (Cairo: Wahid Hamid), which established the new style most memorably. The film is an excellent social comedy that revolved around an unintentional act of "terrorism" in the famous Mugamma" al-Tahrir (a giant building housing parts of seven different ministries). An ordinary man accidentally grabs a security guard's rifle while engaged in a heated argument over bureaucracy; the rifle goes off, and everyone thinks they are under attack. Visually the film partakes of a gritty realist aesthetic that had become prevalent over the past two decades, first in films by elite directors who exhibited their work in international film festivals, but then in ordinary commercial films. Many of these had displayed a cynical and generally negative attitude toward longstanding narratives of progress and modernity. Al-Irhab wal-
} 
The element of Al-Gama ' $a$ that Hamid uses to inject a note of credibility into what is otherwise a quite biased interpretation of history is nostalgia, as mentioned above in my discussion of the modern track of the narrative. In the historical track of the series, nostalgia comes through in the lavish sets and costumes. A 50-million-pound budget afforded uncommonly meticulous attention to detail. No doubt a careful eye could pick out many errors in dress or appearance, but the overall effect was to plunge viewers into the world of interwar Egypt, where everything appeared either more quaint and folkloric, or more like the glory days of colonial modernity, which often are extolled in contemporary neoliberal gentrification initiatives.

The nostalgia was articulated most clearly, at least for me, in the depiction of interwar era Egyptian politicians. Somewhat surprisingly, at least in the context of earlier postindependence filmmaking conventions, ${ }^{19}$ interwar elite politicians are mostly depicted as basically decent and well-meaning. Ali Mahir (Prime Minister in 1936 and again in 1939-40) is a partial exception - he is shown as being Hasan al-Banna's preferred prime minister, which makes him implicitly suspect in the spirit of this production. Also, Sirri Pasha, an old man who served as prime minister during the Second World War, is shown as being weak in the face of British pressure. The young King Faruq, only 16 at the time of his accession in 1936, and a popular ruler in his early years, is depicted as mildly peevish and generally a step behind the older and more politically sophisticated prime ministers. But he is still a nationalist, and there

$K a b a b$, by contrast, suggested that complaints were unconstructive, and that government officials were well-meaning technocrats. The film marked the end of so-called "neorealism" in Egyptian cinema and the first emergence of a narrative style that began moving away from the decaying "old Cairo" (the setting of neorealist films and their commercial imitators) toward exclusive new suburban developments that progressively absorbed more and more of both state and private resources throughout the 1990s and the first decade of the 2000s. On al-Irhab wal-Kabab and its contrast with the neoliberal aesthetic of the 1970s and 1980s see Walter Armbrust (2002) Islamists in Egyptian Cinema, American Anthropologist 104(3): 922-930..

${ }^{19}$ Or more precisely, conventions (generally, as there were always exceptions) of the Nasseri years (1950s and 1960s) and extending through roughly the mid-1980s. The exact moment of historical revision of ancien régime elites (beys and pashas below the level of such famous nationalist figures as Sa'd Zaghlul and Mustafa Kamil) is hard to pinpoint. Certainly, the historical narratives of television writer Usama Anwar 'Ukasha, starting with the first season of Layali alHilmiyya in 1987, were influential in an evolution toward a generally more favorable narrative profile amenable to nostalgia. By 2007, when a largely favourable musalsal depiction of King Faruq was broadcast, one might say that whatever Nasser-era antipathy toward the old elites there may have been had been completely reversed in television and cinema. See, for example, Isma'il 'Abd al-Hafiz (1987) Layali al-Hilmiyya [Hilmiyya Nights] part 1 (Cairo: Qita' alIntaj bil-Tilifizyun al-Misri); and Hatim 'Ali (2007) al-Malik Faruq [King Faruq] (Cairo: Farah Media). 
are only hints of the extravagant lifestyle he fell into by the 1940s. Overall, the series grants the government a certain haybat al-daula — a 'gravity of the state,' or 'prestige,' or one might even say 'awesomeness of the state.' The phrase was never mentioned in the series, but it became a key grievance in counterrevolutionary discourse a couple of years after Al-Gama ' $a$ was broadcast. The idea was that the revolutionaries were besmirching haybat al-daula, and this meant they were trying to destroy the state itself, which was completely unacceptable to a broad cross-section of the country. Restoration of haybat al-daula became a key rhetoric for undermining the legitimacy of the Revolution. Al-Gama ' $a$ had cemented a highly nostalgic image of haybat al-daula before it became an active political issue in real life. In Al-Gama 'a's contrast between the contemporary world of wakil al-niyaba Ashraf and the interwar society of the historical track of the series, one might even see at least a hint of criticism of the Mubarak era, which the series shows as being distinctly lacking in hayba compared to the interwar state.

Wahid Hamid clearly had a soft spot for Wafdist leader Mustafa al-Nahhas. He gets all the best politician lines. At one point in episode 17, al-Nahhas appears at meeting of the Wafd leadership. Several of the others timidly express fears that al-Banna is going to tar them with the brush of being "against religion," which of course means against Islam. Al-Nahhas explodes and gives them an angry lesson in civil society:

I totally reject dragging religion into matters that are not its concern, just as I reject putting any special religious authority over civil authority! Nobody is more careful than I am in honoring and respecting Islam, and nobody is more careful than we are to respect the rule of the constitution. As for the King's constitutional rule, this is of a national scope. It must pertain to all Egyptians, to the entire people. They should celebrate their king, Muslims, Christians and Jews. Religion is for God, and the nation is for all men. ${ }^{20}$

\footnotetext{
${ }^{20}$ Al-Gama, episode 17.
} 
Except for the reference to the King it is a rather modern-sounding speech. One wonders if 'civil authority,' al-sulta al-madaniyya as he puts it, really would have featured in Egyptian Interwar political discourse. There are quite a few other lines in the historical track of the series that put distinctly contemporary words in the mouths of interwar-era politicians.

I do not want to dwell on the nostalgia angle extensively, but I do want to reiterate and emphasize that nostalgia is almost always potentially a commentary on the present by contrast to a better past. The musalsal's positive depiction of the political leadership of the liberal era, which historians have long labelled as a 'failed experiment' in Egyptian political history links naturally to the 'who stole our joy' question raised early on in the modern track of the series. ${ }^{21}$ Of course, Hasan al-Banna and the Muslim Brotherhood are meant to be the thieves, but here we have a positive view of what historians often depict as a dysfunctional political system of interwar Egypt. This dysfunctionality is, to be sure, an oversimplification, but so too is a vision of interwar politics as a united struggle against colonial occupation, interrupted only by disastrous nationalist discord introduced by the Muslim Brotherhood. The British are the main beneficiaries of this nationalist discord, and indeed the series shows them as the architects of it, with the Muslim Brotherhood as their primary instrument.

A scene from episode 12 drives this point home. It builds on a previous scene in which the British intelligence officer recognizes the power that al-Banna is achieving and determines to exploit him. At that point in the narrative the Muslim Brotherhood is just getting started and has to confront the issue of funding. They do this by requiring regular donations as a condition of membership in the organization. It is a gradualist method of funding, and the pace is too slow to fulfill al-Banna's towering ambitions to build not just a national organization, but an international one. When the British get wind of this dynamic, they arrange for the head of the Suez Canal Company, a Frenchman, to donate 500 Egyptian Pounds to al-Banna. Even though the Muslim Brotherhood's ostensible goal is to combat foreign influence in Egypt, al-Banna is

\footnotetext{
${ }^{21}$ A classic formulation of the liberal-era-as-failed-experiment is Afaf Lutfi Marsot (1978) Egypt's Liberal Experiment: 1922-1936 (Berkeley: University of California Press).
} 
not at all reluctant to take money from the Frenchman. In fact, he arrogantly tries to get him to give more, pointing out that the Suez Canal Company had given far more to build churches for foreign workers. The only thing that concerns al-Banna is that at the end of the meeting the Canal Company director tells him a condition of the donation: al-Banna must publicly acknowledge the source of the funds. He doesn't actually do so, but the British arrange for a mainstream preacher to announce it in a sermon. A number of Muslim Brotherhood members are present at the sermon, which makes clear reference to the Brotherhood:

Islam does not differentiate between one Muslim and another. Believers are brothers. A Muslim is the brother of another Muslim. There is no difference between one Muslim and another except for their piety and good works. On the topic of this Society that you're talking about, I have a different opinion. In my opinion this Society is bid'a [heretical innovation]. And all bid'a is error. And on the topic of donations for their mosque, it is not permitted to seek money from an imperialist tyrant, because his money is haram [forbidden by religion]. Its source is haram. Allah is good; He only permits good. $^{22}$

The consequences of the sermon become clear in the following scene, in which the British political officer meets with his aide in the British Embassy.

Aide: The acceptance of cash caused quite a rift between the members [of the Brotherhood] and their leader. They are of the view that it would be a sin to build a mosque with funds from the enemy.

Political Officer: Ah, just as I expected. You do recall my statement that EgyptiansArabs as a whole in fact — will defend religion more fiercely than king and country? Aide: Yes, I recall it sir.

\footnotetext{
${ }^{22}$ Al-Gama, episode 12.
} 
Political Officer: Good. Now let me tell you something of no small importance. When Muslims are united, they become a force to be reckoned with, not to say invincible.

This is why we must always insure they are divided, what? It is most fortunate that they are singularly obdurate when divided by matters of religion. This holy man, this group, will serve us well in creating that rift.

Aide: At the very least they may distract them from us, and all the infernal calls for independence and British evacuation, and of course fill their minds with religious matters.

Political Officer: This group will not remain religious for long. It must turn to politics. If it does not, politics will find it.

Aide: I would never have imagined that 500 pounds could create such a rift.

Political Officer: If you wish to corrupt a holy man you may do one of two things. You may bestow power and position on him, or you may place a sum of money at his disposal.

Aide: So when all is said and done, what do you suggest might be done with this holy man and that band of his?

Political Officer: Why nothing. Nothing at all. We shall act as though unaware of its existence.

Aide: If I may say so sir, I am hardly at ease regarding this group. I fear they may constitute danger to us in the future.

Political Officer: Well it is most natural that such a group, should it continue, might give us a spot of trouble. But in the end, should we lose to it, we stand to lose very little, and to gain considerably. ${ }^{23}$

23 Al-Gama, episode 12. 
It cannot be doubted that the British were aware of the Muslim Brotherhood, at least by the mid-1930s. Gudrun Krämer's biography of Hasan al-Banna quotes a British intelligence official as saying, 'I consider that the 'Moslem Brethren Society' will in the course of time be in a position to produce a reckless and heedless generation who will not abstain from selling their lives cheap and whose best wish would be to die as martyrs for the sake of God and their country. ${ }^{24}$ The same official is quoted as saying that "While [the Muslim Brotherhood] was 'growing in strength,' he believed, it was 'not at present in any way dangerous'." That was in 1936. The scene in Al-Gama ' $a$ in which the British intelligence officer reveals his cunning plan to sow dissension in the otherwise unified ranks of Egyptian nationalists was meant to be in 1927 or so, just as the Muslim Brotherhood was getting started. I leave it to you to the reader to decide whether Wahid Hamid's depiction of the British intelligence agent scene was a plunge into conspiracy theory, or a reasonable interpretation of history.

British manipulation is not the only charge against the Muslim Brotherhood, or even the most serious one. The internationalism of the Muslim Brotherhood, particularly its links to transnational Islamist radicalism, is an even bigger problem in the eyes of Muslim Brotherhood critics. As in the British intelligence agent scene described above, Wahid Hamid embellished the historical record considerably in his portrayal of al-Banna's contacts with foreign Islamic 'radicals,' conflating a wide range of religious figures who had been involved in anti-colonial movements with Wahhabism, and implying that all of them were forms of 'terrorism' or at least inspirations for it. In this vein contacts with Saudi Arabia are mentioned very prominently throughout the series. Al-Banna did in fact admire Saudi Arabia's alliance between the Al Saud family and Wahhabi ideology, as did other Islamic figures of his day. In Al-Gama 'a, al-Banna's admiration for the Saudis was refracted through his interaction with Shaykh Muhibb al-Din alKhatib, who was himself a migrant from Syria, though his family was originally from Baghdad. The son of Abd al-Qadir al-Jilani, the founder of the Qadiriyya Sufi order, al-Khatib was a

\footnotetext{
${ }^{24}$ Gudrun Krämer (2010) Hasan al-Banna (London: Oneworld Publications), p. 82.
} 
Salafi, and a prolific publisher. ${ }^{25}$ Throughout the series, al-Banna is shown seeking al-Khatib's counsel—and this is historically accurate. Al-Banna had many reasons to be friends with alKhatib, but in Al-Gama ' $a$ he functions primarily to highlight connections with austere and fanatical Saudi Islam, which is, by implication, alien to Egypt's 'native' understanding of religion. In Al-Gama 'a, al-Banna's meetings with al-Khatib are sometimes accompanied by ominous background music that leaves no ambiguity about their significance. To ensure that the importance of al-Banna's connection to al-Khatib is crystal clear, the modern track of the series articulates it plainly. In a conversation between Ashraf, the prosecutor, and 'Abdallah, the retired judge and lapsed Muslim Brotherhood member, 'Abdallah notes that:

al-Banna was influenced by Shaykh Muhibb al-Din al-Khatib, and he wasn't just any Shaykh. He was originally from Syria, and was extremely clever at setting up secret and international organizations in the Arab countries. Shaykh Hasan al-Banna learned a lot from him, and developed what he learned.

Ashraf asks 'Abdallah what he means exactly by al-Banna's having 'developed'al-Khatib's expertise in setting up secret organizations. 'Abdallah responds:

Don't forget that in the West at that time there was Fascism in Italy, Nazism in Germany, and Communism in Russia. These were gigantic organizations. For sure Hasan al-Banna benefitted from these organizations. Islamic history is full of secret organizations. For sure Hasan al-Banna studied Shi'ism very carefully. ${ }^{26}$

\footnotetext{
${ }^{25}$ His Salafiyya Bookstore (al-Maktab al-Salafiyya), founded in 1909, and also its later and more famous descendent, the Salafiyya Press and Bookstore (al-Matba'a al-Salafiyya wa-Maktab), were important conduits of both modernist/reformist and conservative Islamic thought; see further Henri Lauzière (2010) Reconsidering Salafism from the Perspective of Conceptual History, International Journal of Middle Eastern Studies 42(3) pp. 369-389.

${ }^{26}$ Al-Gamma', episode no. 13.
} 
So the line runs from al-Khatib to Fascism to Nazism, to Communism, to Shi' ism, seamlessly and completely without evidence. Broadly speaking, al-Khatib was well known to have been an advocate of anti-imperialist causes, and if anything, was a campaigner against Shi ‘ism rather than a crypto-Shi'i as 'Abdallah's grand conflation suggests. One is reminded of Ahmad Musa's certainty about the 'heavy weapons' flooding into Rab'a in my earlier video, the one showing men carrying something wrapped in an Egyptian flag—which he 'knows' is a cannon or a mortar even as he admits in the same utterance that he is no expert in weapons.

'Abdallah does not mention the Saudi connection in the passage quoted above, but another scene does the job very bluntly. It begins with al-Banna arriving at al-Khatib's office in Dar al-Matba'a al-Salafiyya to discuss the publication of a Muslim Brotherhood magazine. While still in a hallway he hears an anguished voice, which he instantly recognizes as that of Rashid Rida, the famed Islamic reformer, known particularly for his writings on the idea of an Islamic state. There is no reason to think that al-Banna was in close contact with Rida. The Muslim Brotherhood was founded in 1927; Rida died in 1935 while returning from the Hajj. Krämer speculates that Rida was too important and well established to have bothered much with a young upstart like al-Banna. ${ }^{27}$ Wahid Hamid, however, had no such reservations, as we see from the dialogue.

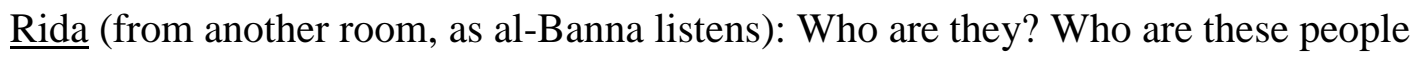
who want to destroy my reputation? Who are these people who want to cast doubt on the soundness of my faith? I am beside myself. My Islam is true! Yes! A sound and true Islam! They're all a bunch of liars ...

Al-Banna (entering): Greetings

Al-Khatib: Greetings. Come in Shaykh Hasan, so you can help comfort Shaykh Rashid. Rida: Ignorant ... they're ignorant!

Al-Banna: Please, don't be so angry.

\footnotetext{
${ }^{27}$ Krämer (2010), Hasan al-Banna, p. 44.
} 
Rida: Hasan my boy, I'm being attacked from all sides

Al-Banna: To hell with them Shaykh Rashid. What's going on here Shaykh Muhibb?

Al-Khatib: Some communist and secularist scoundrels started a mad campaign against him. They say the Shaykh is paid by the Saudis to promote Wahhabism in Egypt.

Al-Banna: What do you think Shaykh Rashid?

Rida: My boy ... I ... I don't think anything.

Al-Banna: And so what, master? So what? It's the truth, and nobody can deny it. Don't the Saudis read your books, just as you buy books by Shaykh Muhibb? Then you advocate what you see in them, and work hard doing it.

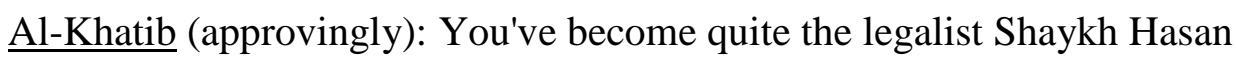

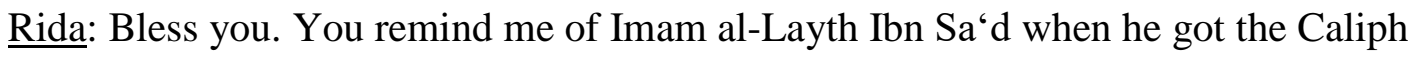
Harun al-Rashid out of a jam ...

Al-Khatib: Shaykh Hasan now has the status of an Imam, Shaykh Rashid

Rida: I was confused, didn't know how to respond, to the point that I thought of saying that King 'Abd al-'Aziz Ibn Sa'ud is my friend, but if I'd said that I'd have put myself in an even worse predicament. May you always be well Hasan.

Al-Khatib: We put all our confidence in Shaykh Hasan.

Rida: Hasan, tell me, does your Society lack for anything?

Al-Banna: Shaykh Rashid, we have many great ambitions.

Rida: Yes. And there are more and greater responsibilities.

Al-Banna: We're now expanding the Society's base and recruiting the best youth.

Al-Khatib: The battle that the Society of Brothers has been waging against Christian missionaries has gained it much fame and sympathy from all Egyptians.

Rida: But fame and love and sympathies aren't what's important. It's enough to defeat and break the enemy. 
Al-Banna: Praise God Shaykh Rashid. We've disgraced them and their methods. We've exposed their incitements, and made the ruler face the danger to religion.

Rida: The Egyptian peoples' faith in Islam is deep, and their zeal for it intense.

The people of Egypt — their feelings of nationalism are violent. My boy, I wish this Society of yours would concern itself with matters of the nation as it does with matters of religion.

Al-Banna (leaning forward with a mischievous grin on his face): But ... this is politics Shaykh Rashid ... ${ }^{28}$

The smirk on al-Banna's face when he says 'this is politics' speaks volumes, neatly fulfilling the British political officer's prediction that the Brotherhood inevitably would put politics ahead of religion. Al-Gama' $a$ endeavors to depict al-Banna as fundamentally cynical, thereby evoking one of the most important excommunication themes - namely that for the Brotherhood foreign allegiances have priority over local roots. Like so much of the historical track of the series, the dialogue has a distinctly contemporary feel. Egypt had not yet recognized Saudi Arabia, but one suspects that Rida would have had little reason to hide his admiration for Wahhabism, and his acute embarrassment at the revelation of his Saudi ties seem implausible. Saudi Arabia of the 1930s was nothing like the oil-rich kingdom that many contemporary Egyptians look at with decidedly conflicted emotions - as a much-resented regional hegemon, as profligate vulgarians with less 'culture' than the proud 7,000-year-old civilization of the Nile Valley, or as the domineering holder of the national purse strings.

One final scene brings us back full circle to the theme of the Muslim Brotherhood's alleged innate violence. This also comes through in one of al-Banna's many contacts with foreign radicals. This time the radical in question is Shaykh Muhammad Sa'id al-'Urfi, a scholar from Deir al-Zur, the largest city in eastern Syria and in our times one of the epicentres of the

\footnotetext{
${ }^{28}$ Al Gama'a, episode 15.
} 
Syrian Civil War. 'Urfi comes calling as a kind of Islamic radical consultant. The exact relationship between him and the Muslim Brotherhood never is spelled out. Presumably, one is meant to apply the Ahmad Musa rule: If you think it looks like a cannon, then it must be a cannon, but in this case substitute 'Islamist radical' for 'cannon.' Al-'Urfi was in truth a kind of transnational Islamic radical—one of the leaders of the Syrian nationalist movement against France in the 1920s and 1930s, a participant in an international conference on Arab unity in Mecca in 1922. When al-Banna first mentions the Syrian's name to his followers and explains where he's from, one of them expresses surprise that he's entertaining people from so far away. Al-Banna admonishes him: 'The people of the Sham are our people, and the people of the Hijaz are our people. All Muslims are our people.' Al-Banna and al-'Urfi stroll about in a park, where 'Urfi offers advice. 'Faith,' he says, 'is the most powerful weapon in life.' But then he goes on with further advice that fits very well with al-Banna's cynical ambition. He tells al-Banna to recruit specifically young men with 'imperfect faith': 'If you know that fear of God resides in their hearts, that they respect order, and that they are obedient, then you'll find that repentance will be forthcoming, and they'll be among the most sincere adherents to you and your $d a$ ' $w a$.' But then he warns al-Banna to avoid two types of people:

The first type is the atheist who has no faith at all, no matter how much piety he might show on the outside. The second type is the truly pious man who does not respect the organization, and will not obey. Whoever will not adhere to the order you impose and will not obey your commands - he is of no use to you or to the Society. His presence will corrupt the Society, will incite it with piety and righteousness, and will divide it with disputes. He will therefore unsettle the straight rank and corrupt it. If people see one person outside the line they won't say 'one 
person has left the line'. Rather they'll say 'the line is crooked'. So beware Hasan. All of your works are contingent on this $d a^{\prime} w a .^{29}$

'Urfi's monologue succinctly illustrates a point that opponents of the Muslim Brotherhood often make, namely that the organization is more concerned with the appearance of faith than with actual piety. Al-Banna drinks in all this advice eagerly. Then he wants to do a kind of show-andtell with his elder radical colleague. He takes al-'Urfi to see his militia in training under the guise of the Muslim Brotherhood's scouting wing:

Al-Banna: Now, Master, I want to accompany you on a short outing that will delight you.

'Urfi: Where are you going to take me Hasan?

[The scene shifts to the two of them walking in the desert; the camera pans across the dunes to show them headed toward some kind of encampment.]

'Urfi: What are the English doing outside their bases?

Al-Banna: These tents have nothing to do with the English. These tents are the Society's - the Society of the Brothers.

'Urfi: What's the Society's purpose out here in the desert Hasan?

Al-Banna: They're the Rovers' vanguard. Strength is a necessity. We won't be the oppressed on earth.

Al-'Urfi: You're preparing these youths to defend the Society, Hasan?

Al-Banna: God willing, though we have more comprehensive and deeper goals Al-'Urfi: explain more Hasan.

Al-Banna: The point isn't just to create an organized means of deterrence, and to train a well-disciplined military force, but rather for these youths to be observed by our

\footnotetext{
${ }^{29}$ Krämer quotes a similar passage by al-'Urfi (Hasan al-Banna, p. 63). But the gist of the passage is less cynical than Wahid Hamid's script - an exhortation to accept new members to the society who were imperfect in their faith, because 'The Islamic call is like a hospital with a doctor who offers treatment, and a patient who seeks such treatment. Do not close the door in their face' (Ibid).
} 
trainers and by me personally, so we know who are the most zealous, the most sincere, the most obedient.

Al-'Urfi: You're choosing your men already Hasan?

Al-Banna: I'm choosing them, choosing them and giving them strong preparation. The $d a$ ' $w a$ can only be built on the shoulders of the strong!

Al-'Urfi: You're just the person for this Hasan. Now I am very well reassured, by you, and by your Society. ${ }^{30}$

The Rovers_-gawwala (jawwala in standard Arabic)—were the Muslim Brotherhood version of the Boy Scouts. The Brotherhood certainly did use its version of scouting to recruit, train and indoctrinate young men, and the organization did have a paramilitary function. However, so did the Wafd, and the Young Egypt movement; all three movements saw the paramilitary nature of scouting as training for actual military use. One might or might not see this as a perversion of scouting - the international scouting organization had a paramilitary character everywhere, though one must allow for the likelihood that local adaptations of it were not necessarily in keeping with the goals of military training. ${ }^{31}$ But what cannot be doubted is that the Brotherhood's Rovers were part of a broad 'healthy spirit in a healthy body' movement that originated in Europe, and was global. Krämer writes that the Muslim Brotherhood version of scouting included specific kinds of indoctrination, such as 'reference to the hero-warriors of the early Islamic period, prayer and night vigils. ${ }^{32}$ The Brotherhood also employed Sufi practices of self-discipline, and required members to study some of the writings of Hasan alBanna. Later, some of the Rovers were recruited to form small 'battalions' (kata'ib), some of which fought in Palestine, others against the British, and probably also against the local Jewish

\footnotetext{
${ }^{30}$ Al Gama'a, episode no. 12.

${ }^{31}$ On this matter I speak from my own experience of several years of decidedly un-militaristic scouting in the $1970 \mathrm{~s}$. We wore uniforms and stood in formation, and most of us saw that part of scouting as a joke. Scouting in 1970s suburban Omaha was closer to proto-environmentalism with the added advantage that it afforded treasured moments of independence from parental authority.

${ }^{32}$ Krämer, Hasan al-Banna, p. 91.
} 
community in 1948. The point is not to say that Wahid Hamid's interpretation of the

Brotherhood's Rovers was completely outlandish. Rather Hamid cleverly and pointedly undercontextualized the Brotherhood's scouting activities. We understand al-Banna's Rovers differently if we put them in the context of international scouting-a global movement, everywhere taking a paramilitary form, and everywhere connected both to nation and to religion. The Brotherhood's emphasis on 'hero-warriors of the early Islamic period' seems to be permissible within the franchise model of global scouting. One finds, for example, a contemporary Arab Christian scouting poster displaying St. George--the most venerated saint in the Crusades--slaying the dragon in its upper left corner. ${ }^{33}$ In the abstract, that sounds at least as aggressive as the Brotherhood's emphasis on hero-warriors. However, neither is out of line with the way scouting has worked everywhere. The Scouting Oath, in both Arabic and English, states: 'On my honor I will do my best to do my duty to God and my Country.' One widespread Arabic translation of the passage is more explicit about priorities than the original English: $U^{\prime} i d$ sharafi bi-an aqumu bi-wajibi nahwa Allah, thumma al-watan... ; [I pledge my honor to do my duty to God and then to my country ...']. ${ }^{34}$ But aside from such nuances, it is the same scouting oath I learned in the 1970s. God comes first in most versions of the international Scouting Oath. There was no need for the Brotherhood to introduce putting God above nation in their Rover indoctrination. It was already there.

But connecting the Rovers to actual scouting was the last thing Wahid Hamid wanted to do. His point rather was to connect the Rovers as a militia of the Muslim Brotherhood that was represented in the contemporary track of the series. It is the visual equivalent of retired judge

\footnotetext{
${ }^{33}$ Al-Wa'd al-Kashfi (2017) Kashfiyyatna (International Catholic Conference of Scouting Arabic branch): http://www.cicsjo.org/images/ind/Scout.jpg, accessed 24 July 2018. It should be noted, however, that St. George was a complex figure historically, and at least in some times and places may have been interpreted positively by Muslims. See H.S. Haddad (1969) 'Georgic' Cults and Saints of the Levant. Numen 16, Fasc 1: 21-39.

${ }^{34}$ Some translations use the more neutral formulation of Allah wal-Watan' ('God and country'), but often the more subtly prioritized formulation putting God over country is repeated, for example in Mansoura Scout (2017) 'Ashira Kulliyat al-Tugara Jami 'at al-Mansura [The Faculty of Commerce Troupe in Mansura University]: http://tegascout.ba7r.org/t169-topic accessed on 25 July 2018). The original formulation in 1908 used the formula "God and the King," but was adapted to international contexts as the movement grew, but in most cases God remains part of the formulation.
} 
‘Abdallah's above-quoted conflation: Muhibb al-Din al-Khatib, to Fascism, Nazism, Communism, and Shi 'ism. In this case it is the Rovers in the 1930s to the militia parading at alAzhar University in 2006. Following this logic, one requires only a short step to television propagandist Ahmad Musa's unshakeable certainty that he was seeing a video of a cannon being carried into Rab'a al-'Adawiyya, making the protestors there fair game for anything the state security forces might do to them. It is easy to see how a de-historicized public might have internalized the notion that violence is encoded in the DNA of the Muslim Brotherhood.

\section{Conclusion}

In concluding, I do not want to be misunderstood as arguing that the Muslim Brotherhood never has been involved in political violence; of course it has. Rather, I argue that political violence needs to be understood in its historical context, and not through a distorting narrative that assigns to it an unchanging essence that can be suppressed or eradicated, but never evolves, is never subject to internal critique, and affects all individuals uniformly.

Secondly, I want to reiterate a point made earlier about the role of preconceptions in the massacre at Rab'a al-'Adawiyya in 2013. Many observers were shocked by the ferocity of the event. Many tried to explain the massacre and implicitly justify it as an outcome of the revolutionary politics that emerged in 2011. Such justifications are often anecdotal, but they sometimes emerge in formal academic writing. For example, Hazem Kandil's book, Inside the Brotherhood, starts with an introductory frame predicated on the Egyptian public having been shocked by their first real view of the Muslim Brotherhood only when they came to power in 2012. The Brotherhood, he contends, was:

different from what they were used to from the normally polished Brothers: political competitors were religiously condemned; images of Prophet Muhammad's epic battles were conjured; biblical stories, from David and Moses to Armageddon, were invoked; claims that Archangel Gabriel prayed at the Islamist campsite were flaunted; 
and sacred visions were relayed on stage night after night. This was not the vocabulary Brothers typically employed in their public interactions. Almost overnight, many Egyptians panicked. Who were these strangers, they wondered $?^{35}$

One should not judge Inside the Brotherhood, a book based on a great deal of empirical research, entirely by its introductory framing. But the image of an otherwise open-minded public 'panicked' from the images of the Rab'a sit-in strikes me as quite implausible. The groundwork for excommunicating the Brotherhood already had been laid prior to the Revolution. Al-Gama 'a was the most elaborate and instantiation of excommunication discourse that the Egyptian public had experienced in a narrative form (and for many in any form outside a conversational setting). It was precisely the existence of this discourse that facilitated the likes of Ahmad Musa putting the nail in the protestors' coffins by loudly asserting outrageous falsehoods about what they were doing.

My final point is about television generally. Academics pay insufficient attention to it, and I include myself in this criticism. Academics who make a living entirely from writing about Middle Eastern television serials are exceedingly rare, and the number whose professional profile focuses primarily on television generally (as opposed to the dramatic serial form, which remains the most popular genre on the small screen) is not much larger. But television surely matters much more than one might think from surveying academic literature. Al-Gama 'a anticipated all the arguments that would be used against the Muslim Brotherhood during the Revolution. One could not have used it to predict events. Prediction is for fools and think-tanks. Anticipation, however, is a different matter. A couch potato academic devoted to watching musalsals would have been less shocked and less perplexed by Rab'a than a serious scholar who follows democratization theory, Islamic movements, and political transition. It should be emphasized that Al-Gama' $a$ was by no means an outlier. One could say that it functioned as the 'seal of the prophets' - the final and most complete revelation of the prophetic message, but also

\footnotetext{
${ }^{35}$ Kandil, Inside the Brotherhood, 1-2.
} 
the last in a long line of revelations. For 'prophetic message' substitute 'anti-Brotherhood propaganda.' The ultimate fulfilment of prophecy in this case was a massacre. A massacre foretold.

\section{Acknowledgements}

A different version of this text will appear in Martyrs and Tricksters: An Ethnography of the Egyptian Revolution (forthcoming, Princeton University Press, 2019). The Martyrs and Tricksters chapter is very differently contextualized, as part of an analysis of revolution as a liminal crisis leading to the rise of trickster politicians. There is substantial overlap between the two texts, but they have evolved on separate tracks, and come to different conclusions. Both originate from a keynote address at a conference on History and Society on TV in the Middle East held at the University of Maryland on April 62017.

\section{References}

'Abd al-Hafiz, I. (1987) Layali al-Hilmiyya [Hilmiyya Nights], part 1 (Cairo: Qita' al-Intaj bilTilifizyun al-Misri). 
'Ali, H. (2007) al-Malik Faruq [King Faruk] (Cairo: Farah Media).

'Arafa, S. (1992) al-Irhab wal-Kabab [Terrorism and Kebab] (Cairo: 'Isam Imam).

'Arafa, S. (1991) al-Lu'b ma' al-Kubar [Playing with the Gownups] (Cairo: Wahid Hamid).

Armbrust, W. (2002) Islamists in Egyptian Cinema. American Anthropologist 104 (3): 922-930.

Armbrust, W. (forthcoming) Martyrs and Tricksters: An Ethnography of the Egyptian Revolution (Princeton: Princeton University Press).

'Asliha Thaqila fi Rab'a' [Heavy Weapons in Rab'a] (2013) Youtube video from a report in the newspaper al-Yaum al-Sabi ', 29 July. Available at: https://www.youtube.com/watch?v=cfA9qWK8eS8. Accessed on 24 July 2018.

Al-Buhairi, A. (2006) Milishiyat 'Ikhwaniyya' Tasta'rad Maharat Qitaliyya Dakhil Jami'at alAzhar [Brotherhood Militias Show Off their Fighting Skills inside Al-Azhar University]. Al-Masry al-Yaum, Nov. 12). Available at: http://today.almasryalyoum.com/article2.aspx?ArticleID=40525. Accessed 24 July 2018.

Butler, J. (2009) Frames of War: When is a Life Grievable? (London: Verso).

Al-Dib, Y. (2012) Wahid Hamid: Ga'izat al-nil Takhtar Man Yahmiluha [Wahid Hamid: the Nile Prize Selects One Who Merits It] In: Al-Qahira, archived in Masress. Available at: Suits It]. Accessed 25 July 2018.

Fadiha min al-'Ayar al-Thaqil Shuf Jihad al-Nikah fi Rab'a al-'Adawiyya [A Scandal of the Greatest Magnitude: See the Jihad of Marriage in REab'a al-'Adawiyya] (2013) Youtube video available at: https://www.youtube.com/watch?v=PvzwkyVSDxA. Accessed 5 December, 2018.

Farghali, D. (2013) Al-Liwa' Faruq al-Maqrahi: Fadd I'tsamay Rab'a wa Nahda Yakun 'ala 3 Marahil [General Faruq al-Maqrahi: The Dispersal of the Ra'a and Nahda Occupations in Three Stages]. In: al-Watan (archived in Masress), 3 August. Available at: https://www.masress.com/elwatan/237512. Accessed 24 July 2018.

Haddad, H. S. (1969) 'Georgic' Cults and Saints of the Levant. In: Numen 16, Fasc 1: 21-39.

Haqiqat Milishiyat al-Ikhwan fi al-Azhar [The Truth about the Brotherhood Militias in alAzhar] (2006) Youtube video available at: https://www.youtube.com/watch?v=B 2sFWzj4E. Accessed 24 July 2018.

Human Rights Watch (2014) All According to Plan: The Rab 'a Massacre and Mass Killings of Protestors in Egypt (New York: Human Rights Watch).

Kandil, H. (2014) Inside the Brotherhood (Cambridge, UK: Polity Press).

Ketchley, N. \& Biggs, M. (2015) Who Actually Died in Egypt's Rabaa Masacre? In: Washington Post, August 14. Available at: http://www.washingtonpost.com/blogs/monkey-cage/wp/2015/08/14/counting-the-deadof-egypts-tiananmen/. Accessed 24 July 2018.

Krämer, G. (2010) Hasan al-Banna (London: Oneworld Publications).

Lauzière, H. (2010) The Construction of Salafiyya: Reconsidering Salafism from the Perspective of Conceptual History. In: International Journal of Middle Eastern Studies, 42(3), pp. 369-389.

'Mansoura S. (2017) 'Ashira Kulliyat al-Tugara Jami 'at al-Mansura [The Faculty of Commerce Troupe in Mansura University]. Available at: http://tegascout.ba7r.org/t169-topic. Accessed 25 July 2018. 
Marsot, A. L. (1978) Egypt's Liberal Experiment: 1922-1936 (Berkeley: University of California Press).

Al-Masry al-Yaum (2013) 'I'tisam Rab'a al-'Adawiyya: al-Ta'dhib bi-Ism al-Shar'iyya [The Rab'a al-'Adawiyya Occupation: Torture in the Name of Legitimacy], July 22. Available at: http://www.almasryalyoum.com/news/details/239210. Accessed 25 July 2018.

Milishiyat al-Ikhwan fi al-Azhar [The Brotherhood Militias in al-Azhar] (2012 [from 2006])Youtube video, available at: https://www.youtube.com/watch?v=VMPpGR-Pc3k. Accessed 24 July 2018.

'Taqrir Shamil: Hasr Dahaya Fadd I'tsam Rab'aa Tafsiliyan' [The Complete Report: The Tally of Victims of the Dispersal of Rab'a in Detail] (2013) In: Wikithaura. Available at: http://wikithawra.wordpress.com/2013/09/03/rabiadisperal14aug/. Accessed 24 July 2018.

Al-Tayyib, 'Atif. (1986) Al-Bari' [The Innocent] (Cairo: Samira Ahmad \& Safwat Ghattas).

Al-Wa'd al-Kashfi (2017) Kashfiyyatna (International Catholic Conference of Scouting, Arabic branch). Available at: http://www.cicsjo.org/images/ind/Scout.jpg. Accessed on 24 July 2018.

Wahid H. (2018) Elcinema. Available at: http://www.elcinema.com/person/1087034/. Accessed 25 July 2018.

Waqa'i' al-Hadath (2013) 'Al-Mukhabarat al-Amrikiyya Tarsud Asliha wa Qanabil bi-Dakhil I'tisam Rab ' $a$ ' [American Intelligence Monitors Weapons and Bombs Inside the Rab'a Occupation], 29 July. Available at: http://www.elhadasnews.com/28279.html. Accessed 24 July 2018.

Yasin, M. (2010) Al-Gama'a (The Society) (Cairo: Sharikat al-Batrus lil-Intag al-Fanni wa alTauzi').

Yusuf, N. (2010) Jadal Haula Musalsal 'al-Jama'a' al-Misri [Arguments about the Egyptian Series al-Jama'a], Qantara, 7 September. Available at: http://ar.qantara.de/content/jdlhwl-mslsl-ljm-lmsry-mslsl-ljm-hrb-lmy-m-drm-fny. Accessed on 25 July 2018. 